\title{
Grazing Management Effects on Sediment and Phosphorus in Surface Runoff
}

\author{
Mathew M. Haan, ${ }^{1}$ James R. Russell, ${ }^{2}$ Wendy J. Powers, ${ }^{3}$ \\ John L. Kovar, ${ }^{4}$ and Jamie L. Benning ${ }^{5}$ \\ Authors are ${ }^{1}$ Assistant Scientist, ${ }^{2}$ Professor, and ${ }^{3}$ Associate Professor, Dept of Animal Science, Iowa State University, \\ Ames, IA 50010; ${ }^{4}$ Soil Scientist, USDA-ARS National Soil Tilth Laboratory, Ames, IA 50011; and \\ ${ }^{5}$ Extension Water Quality Educator, University of Nebraska, Lincoln, NE 68583.
}

\begin{abstract}
Sediment and phosphorus $(\mathrm{P})$ in runoff from pastures are potential non-point-source pollutants in surface waters that may be influenced by surface cover, sward height, treading damage, surface slope, soil moisture, and soil P. The objectives of the current study were to quantify sediment and total P loads in runoff produced during simulated rainfall from pastures and to evaluate their relationships with the physical and chemical characteristics of the soil and sward. Five forage management treatmentsungrazed $(\mathrm{U})$, hay harvest/fall stockpile grazing $(\mathrm{HS})$, continuous stocking to a sward height of $5 \mathrm{~cm}(5 \mathrm{C})$, and rotational stocking to sward heights of $5(5 \mathrm{R})$ or $10(10 \mathrm{R}) \mathrm{cm}$-were established in triplicate 0.40 -ha paddocks in 3 smooth bromegrass (Bromus inermis Leyss.) pastures for 3 years. Rainfall simulations were conducted at a rainfall intensity of $7.1 \mathrm{~cm} \cdot h^{-1}$ for 1.5 hours over a $0.5-\mathrm{m}^{2}$ area in 3 locations at 2 slope ranges in each paddock in June, August, and October of each year and the subsequent April. Forage management did not affect mean sediment load $\left(7.3 \pm 5.0 \mathrm{~kg} \cdot \mathrm{ha}^{-1} \cdot \mathrm{h}^{-1}\right)$. Mean total P load was greatest from $5 \mathrm{C}$ treatment $\left(0.071 \pm 0.011 \mathrm{~kg} \cdot \mathrm{ha}^{-1} \cdot \mathrm{h}^{-1}\right)$, did not differ among the U, HS, and 10R treatments $\left(0.019 \pm 0.011 \mathrm{~kg} \cdot \mathrm{ha}^{-1} \cdot \mathrm{h}^{-1}\right)$, and was intermediate in the $5 \mathrm{R}$ treatment $\left(0.053 \pm 0.011 \mathrm{~kg} \cdot \mathrm{ha}^{-1} \cdot \mathrm{h}^{-1}\right)$. Of the soil and sward characteristics measured, percentage surface cover was most highly related to sediment load $\left(R^{2}=0.16\right)$ and total $\mathrm{P}$ load $\left(R^{2}=0.10\right)$. Surface runoff from pastures managed to maintain adequate residual forage cover did not contribute greater sediment or $\mathrm{P}$ to surface waters than an ungrazed grassland.
\end{abstract}

\section{Resumen}

Los sedimentos y fósforo $(\mathrm{P})$ contenidos en los escurrimientos provenientes de los praderas son fuentes potenciales de contaminación no puntual de las aguas superficiales que pueden estar influenciados por la cobertura del suelo, altura de la pradera, el daño por pisoteo, la pendiente de la superficie, la humedad y P del suelo. Los objetivos del presente estudio fueron cuantificar los sedimentos y cargas totales de P en el escurrimiento producido durante lluvias simuladas en praderas y evaluar sus relaciones con las características físicas y químicas del suelo y la pradera. Se establecieron cinco tratamientos de manejo del forraje: sin apacentamiento (U), cosecha de heno/ almacenamiento en pie en otoño (HS), apacentamiento continuo de la pradera hasta los 5 $\mathrm{cm}$ de altura del rastrojo (5C), apacentamiento rotacional hasta $5 \mathrm{~cm}(5 \mathrm{R})$ y $10 \mathrm{~cm}(10 \mathrm{R})$ de altura del rastrojo. Los tratamientos se establecieron por triplicado en potreros de 0.40 ha en tres praderas de "Smooth bromegrass" (Bromus inermis Leyss.) durante tres años. Las simulaciones de lluvia se condujeron a una intensidad de $7.1 \mathrm{~cm} \cdot \mathrm{hr}^{-1}$ por 1.5 horas sobre un área de $0.5-\mathrm{m}^{2}$ en tres puntos y dos rangos de pendiente en cada potrero y se llevaron a cabo en Junio, Agosto y Octubre de cada año y en Abril del año siguiente. El manejo del forraje no afectó la media de carga de sedimento $\left(7.3 \pm 5.0 \mathrm{~kg} \cdot \mathrm{ha}^{-1} \cdot \mathrm{h}^{-1}\right)$. La media de la carga de $\mathrm{P}$ total fue mayor en el tratamiento $5 \mathrm{C}\left(0.071 \pm 0.011 \mathrm{~kg} \cdot \mathrm{ha}^{-1} \cdot \mathrm{h}^{-1}\right)$, fue igual entre los tratamientos U, HS y $10 \mathrm{R}$ $\left(0.019 \pm 0.011 \mathrm{~kg} \cdot \mathrm{ha}^{-1} \cdot \mathrm{h}^{-1}\right)$ y fue intermedia en el tratamiento $5 \mathrm{R}\left(0.053 \pm 0.011 \mathrm{~kg} \cdot \mathrm{ha}{ }^{-1} \cdot \mathrm{h}^{-1}\right)$. De las características del suelo y la pradera medidas, el porcentaje de cobertura fue el más altamente relacionado con la carga de sedimento $\left(R^{2}=0.16\right)$ y la carga de P total $\left(R^{2}=0.10\right)$. El escurrimiento superficial proveniente de las praderas manejadas para mantener una cobertura adecuada de forraje residual no contribuyó con más sedimentos o $\mathrm{P}$ a las aguas superficiales que un pastizal sin apacentamiento.

Key Words: cattle, non-point-source pollution, nutrients, rainfall simulation, water quality

\section{INTRODUCTION}

Research was funded, in part, by the lowa Agricultural and Home Economics Experiment Station, Ames, IA, and by grants from the lowa Dept of Natural Resources, lowa State University Leopold Center for Sustainable Agriculture, and the lowa State Water Resources Research Institute.

Correspondence: James Russell, Dept of Animal Science, lowa State University, 337 Kildee Hall, Ames, IA 50010. Email: jrussell@iastate.edu

Manuscript received 13 September 2005; manuscript accepted 23 July 2006.
Erosion of sediment and transport of nutrients in surface runoff are natural processes that may be accelerated by land management practices (Smeck 1985). Soil losses from forage systems are generally low (Gard et al. 1943) because of improved soil structure (Entz et al. 2002), increased soil microporosity (McDowell et al. 2003), rainfall infiltration (Alderfer and Robinson 1947), protection of soil surface from raindrop impact (Pearce et al. 1998), and filtration of sediment from surface runoff (Pearce et al. 1998). Despite the benefits 
associated with forage production systems, several reports have implicated livestock grazing in the degradation of surface water quality (CAST 2002; Gillingham and Thorrold 2000).

Cattle grazing may reduce the hydraulic conductivity of the soil. Damage caused by treading (Elliott et al. 2002), decreased soil organic matter (Naeth et al. 1991b; Betteridge et al. 1999), and reduced leaf litter results in a reduction of aboveground water-holding capacity of the soil (Naeth et al. 1991a), decreasing infiltration rate and increasing the volume of surface runoff. Management practices that reduce the total volume of surface runoff and encourage infiltration will reduce the potential for sediment and P losses from pastures (Gburek et al. 2000).

Maintaining optimum pasture cover and allowing litter to accumulate on the soil surface can preserve forage plant vigor, improve soil structure, stabilize sediment, and reduce the movement of nutrients from pastures into streams (Naeth et al. 1991b, 1996; Clary and Leininger 2000). Rotational stocking systems and hay harvest have been shown to reduce the amount of bare ground and maintain an adequate forage canopy in pastures, as opposed to continuous stocking, so that excessive soil erosion and nutrient transport to surface waters are prevented (Gilley et al. 1996; Manley et al. 1997). The objectives of the current study were to quantify the losses of sediment and total $\mathrm{P}$ in surface runoff produced by simulated rainfall in pastures with different management practices and to determine the relationships among the soil and forage characteristics of the pastures and those losses.

\section{MATERIALS AND METHODS}

\section{Site Description}

For 3 years, 2001-2003, pastures located at the Iowa State University Rhodes Research and Demonstration Farm (lat $42^{\circ} 00^{\prime} \mathrm{N}$, long $93^{\circ} 25^{\prime} \mathrm{W}$ ) were managed to determine the impacts of beef cow grazing on sediment and $\mathrm{P}$ losses in surface runoff from pastures. Pastures had slopes of $0^{\circ}-15^{\circ}$ and were primarily composed of smooth bromegrass (Bromus inermis Leyss). Soils at the study site were characterized as Downs silt loam (fine-silty, mixed, mesic Mollic Hapludalf), Gara loam (fine-loamy, mixed, mesic Mollic Hapludalf), and Colo-Ely complex (fine-silty, mixed, mesic, Cumulic Haplaquoll, and finesilty, mixed, mesic, Cumulic Hapludoll). Thirty-year average annual precipitation at the research site was $891 \mathrm{~mm}$, with the majority of the precipitation falling from May through July. Precipitation was slightly above average during the first $(932 \mathrm{~mm})$ and third years $(965 \mathrm{~mm})$ of the study and slightly below average during the second year (716 mm; NOAA 2001, 2002, 2003, 2004). Prior to initiation of the study, all pastures were managed as a single unit for grazing of beef cattle and hay harvest.

Three 2.2-ha pastures were located on hillsides with a north, south, or east aspect and subdivided into 5 0.4-ha paddocks with a 6-m wide lane at the top of the hill for cattle movement. Soil samples were taken prior to the initiation of stocking in April 2001 for determination of plant available (Bray-I) P and exchangeable potassium $(\mathrm{K})$ by the Iowa State University Soil Testing Laboratory. Based on test results, $\mathrm{P}$ was applied as diammonium phosphate to 2 paddocks in 1 pasture to bring all paddocks to a minimum of $11-15 \mathrm{mg} \cdot \mathrm{kg}^{-1}$, a concentration considered optimum for cool-season grass pastures in Iowa
(ISU 2002). Soils in all paddocks contained an optimum level $\left(111-150 \mathrm{mg} \cdot \mathrm{kg}^{-1}\right)$ or greater of exchangeable K; therefore no additional $\mathrm{K}$ was applied. Neither $\mathrm{P}$ nor $\mathrm{K}$ was applied for the remainder of the study period. In all 3 years, $\mathrm{N}$ was applied to all paddocks as urea at a rate of $90 \mathrm{~kg} \mathrm{~N} \cdot \mathrm{ha}^{-1}$ before the initiation of grazing in the spring and $50 \mathrm{~kg} \mathrm{~N} \cdot \mathrm{ha}^{-1}$ in midAugust. Sandbags were placed around the perimeter of the pastures and between adjacent paddocks to prevent contamination from surface runoff during natural rainfall events.

\section{Forage Management}

Forage management treatments were randomly assigned to 1 of 5 paddocks in each pasture. Treatments included an ungrazed control (U), summer hay harvest with fall stockpile grazing to a residual sward height of $5 \mathrm{~cm}$ (HS), continuous stocking to a residual sward height of $5 \mathrm{~cm}(5 \mathrm{C})$, and rotational stocking to a residual sward height of $5(5 \mathrm{R})$ or $10(10 \mathrm{R}) \mathrm{cm}$. Paddocks were initially stocked with three nonpregnant mature Angus cows (mean body weights of $657 \pm 84,613 \pm 94$, and $625 \pm 53 \mathrm{~kg}$ in years 1,2, and 3, respectively) in May of each year. Summer grazing was terminated in October of each year. Animals had access to salt but received no supplemental $\mathrm{P}$ while on the research pastures.

In the continuous stocking system, cattle were removed from the paddocks when the sward height, measured with a falling plate meter $\left(4.8 \mathrm{~kg} \cdot \mathrm{m}^{-2}\right.$; Hermann et al. 2002), decreased to $5 \mathrm{~cm}$. Paddocks were allowed a short rest period of 7-10 days to provide for limited forage regrowth. These short rest periods in the continuous stocking system were considered to be representative of cattle distribution patterns in a larger pasture. Cattle allowed continuous access to a large pasture will avoid areas of low forage availability in favor of areas of greater forage availability (Pinchak et al. 1991), effectively providing the area of low forage availability a short rest period for forage regrowth to occur. The 5C treatment allowed an average of $429 \mathrm{cow}$-day $\cdot \mathrm{ha}^{-1}$ grazing per year.

In the rotational stocking systems, cattle were removed from the paddocks when the sward height decreased to 5 or $10 \mathrm{~cm}$ for the $5 \mathrm{R}$ and $10 \mathrm{R}$ treatments, respectively. In both rotational stocking systems, paddocks were allowed 35 -day rest periods for plant regrowth before being restocked. The $5 \mathrm{R}$ and $10 \mathrm{R}$ treatments allowed 337 and $272 \mathrm{cow}-\mathrm{day} \cdot \mathrm{ha}^{-1}$, respectively, of grazing per year.

Hay was harvested from the HS treatment in June of each year. Regrowth from these paddocks was mowed in early August of each year to improve forage quality during the stockpile-grazing period (Fribourg and Bell 1984), but the yield of clipped forage was inadequate to harvest. Paddocks in the HS system were stocked in mid-November of each year, following a killing frost, with three cows that had been used during the previous summer grazing period and grazed to a residual sward height of $5 \mathrm{~cm}$. An average of $3202 \mathrm{~kg} \cdot \mathrm{ha}^{-1}$ of hay were harvested, and $63 \mathrm{cow}$-day $\cdot \mathrm{ha}^{-1}$ of grazing occurred during the stockpile grazing period of each year from the HS treatment.

\section{Rainfall Simulations}

Rainfall simulations were conducted in the late spring (June), midsummer (August), and fall (October) of each year and in the 
early spring (April) the following year to determine infiltration rate, percentage precipitation lost as surface runoff, and amounts of sediment and P lost in surface runoff. Six simulation sites were selected within each paddock so that 3 were in low $\left(1^{\circ}-7^{\circ}\right)$ and 3 were in high $\left(7^{\circ}-15^{\circ}\right)$ slope areas. Rainfall simulation sites were marked with fiberglass posts so that the same locations could be returned to during subsequent rainfall simulation periods throughout the 3-year study period. If cattle defecated on a rainfall simulation site, no attempt was made to remove feces prior to rainfall simulation or to reposition the simulator to avoid fecal material. Rainfall simulations were conducted with drip-type simulators measuring $1.0 \times 0.5 \mathrm{~m}$ (Bowyer-Bower and Burt 1989) positioned so that the long side was running with the slope of the hill. Simulators were assembled so that the uphill side of the simulator was $1 \mathrm{~m}$ above the soil surface, allowing simulated rainfall to reach $56 \%$ of terminal velocity (Gunn and Kinzer 1949). Each rainfall simulation ran for 1.5 hour at a precipitation rate of $7.1 \mathrm{~cm} \cdot \mathrm{h}^{-1}$, corresponding to a storm event with a 50 -year recurrence interval (Huff and Angel 1992). Municipal water, filtered through a $0.45-\mu \mathrm{m}$ filter to remove particulate matter $(\mathrm{pH} 7.89$, electrical conductivity $316 \mu \mathrm{S}$ ), was used as the source water for rainfall simulations. During simulations, amounts of rainfall and runoff were measured at 10-minute intervals, and runoff was composited by simulation. At the completion of each rainfall simulation, collection tanks were agitated, and a 1-L subsample was retained for analysis. Rainfall infiltration rate was calculated as the volume of rainfall applied minus the runoff volume divided by the area of the simulation site and expressed as millimeters per hour. Percentage surface runoff was calculated as the volume of surface runoff collected divided by the volume of rainfall applied over the 90 -minute rainfall simulation period multiplied by 100 .

\section{Soil and Forage Measurements}

Prior to rainfall simulations, surface roughness was measured using a $2-\mathrm{m}$ pin meter with 41 pins and calculated as the standard deviation of the length of adjacent pins on the pin meter (Betteridge et al. 1999). Vegetative ground cover was determined as 1 minus the percentage pins on the pin meter striking soil at each site (Betteridge et al. 1999). During simulations, soil samples $(0-5 \mathrm{~cm}$ depth) were taken adjacent to each simulation site for determination of Bray-1 P and antecedent soil moisture. Penetration resistance was measured adjacent to the rainfall simulation sites at $3.5-\mathrm{cm}$ intervals to a depth of $35 \mathrm{~cm}$ using a Bush Recording Penetrometer (Findley, Irvine, Midlothian, Scotland) with a 12.9-mm-diameter cone prior to each rainfall simulation. When penetration resistances exceeded $4572 \mathrm{kPa}$, the maximum resistance that the instrument could measure, this value was used for statistical analysis. Sward height was measured with a falling plate meter, and a forage sample was clipped to a height of 2.5 $\mathrm{cm}$ from a $0.25-\mathrm{m}^{2}$ area adjacent to the rainfall simulation site, with the same sward height as the simulation site.

\section{Laboratory Analysis}

Water samples were stored at $4^{\circ} \mathrm{C}$ until analysis for total suspended solids and total P. Sediment and P concentrations in the input water were subtracted from the runoff samples. Total suspended solids were determined by filtering a $100-\mathrm{ml}$ water sample through a preweighed $0.45-\mu \mathrm{m}$ filter paper. Filter papers were oven dried (APHA 1995) at $105^{\circ} \mathrm{C}$ for 24 hours and weighed. Total $\mathrm{P}$ concentration was determined by digestion of $2.5-\mathrm{ml}$ samples, followed by colorimetric analysis with the ascorbic acid method (AOAC 2003). Sediment and total P loads, $\mathrm{kg} \cdot \mathrm{ha}^{-1} \cdot \mathrm{h}^{-1}$, were calculated by multiplying the concentration of each component by the total runoff volume from each rainfall simulation area.

Soil $\mathrm{P}$ concentrations were determined using the Bray-1 P procedure (Bray and Kurtz 1945). Gravimetric soil moisture was determined by drying samples at $105^{\circ} \mathrm{C}$ for 24 hours and weighing. Forage samples were oven dried at $65^{\circ} \mathrm{C}$ for 48 hours and weighed to determine forage mass.

\section{Statistical Analysis}

Data were analyzed using the PROC MIXED procedure of SAS (SAS 1999). The model included treatment, slope, year, season, and their interactions as fixed effects and replicate as a random effect. No runoff occurring during several simulated rainfall events resulted in a large number of zero values for percentage runoff, as well as sediment and total P loads in runoff and a large proportion of high values for infiltration rate; as a result these variables had a nonnormal distribution. Nonnormality could not be corrected by data transformation; these variables were analyzed using a Monte Carlo method (Gonzalez and Manly 1998) in S-Plus (Venables and Ripley 1994) to determine differences. The effect of treatment on the percentage of simulations not producing runoff was analyzed using an arc sine transformation to equalize variance. If no surface runoff occurred during a given rainfall simulation, sediment and total $\mathrm{P}$ concentrations from those events were excluded from analysis. Least square means $( \pm$ SEM) are reported in text and tables. Multiple comparisons for values with significant treatment effects were tested using the Tukey method, and significance was determined at $P<0.05$ with a tendency for significance at $P \leq 0.10$.

Stepwise multiple regressions were performed using the PROC REG procedure of SAS (SAS 1999) to determine the relationships among the measured forage (sward height, surface cover, forage mass), soil (soil moisture, Bray-1 P, penetration resistance at $3.5-\mathrm{cm}$ intervals to a depth of $35 \mathrm{~cm}$ ), and site characteristics (surface slope) and the dependent variables of infiltration rate, surface runoff, sediment load, and total P load. Slope was included in the data set as the sine of slope in radians because this measure provides a more accurate representation of the flow shear stress of runoff water (Liu et al. 1994). Variables not significant at $P<0.15$ were excluded from the model.

To more clearly evaluate the relationship of $P$ concentrations in runoff water and available $P$ in surface $(0-5 \mathrm{~cm})$ soil, data from each of the five treatments were subjected to linear regression analysis. Values for total P and Bray-1 extractable $P$ were log transformed to produce normal distributions and equal error variances. Zero concentrations were considered missing values for these analyses.

\section{RESULTS AND DISCUSSION}

\section{Treatment Effects}

Forage management practices that maintain high levels of soil organic matter, litter, and vegetative cover have been shown to 
Table 1. Least squares means of runoff and sediment, total $P$ concentrations and load during rainfall simulations from paddocks with different forage management treatments.

\begin{tabular}{|c|c|c|c|c|c|c|c|}
\hline & \multicolumn{5}{|c|}{ Treatment $^{1}$} & \multirow[b]{2}{*}{$\mathrm{SEM}^{2}$} & \multirow[b]{2}{*}{$P$ value $^{3}$} \\
\hline & U & HS & $10 \mathrm{R}$ & $5 R$ & $5 \mathrm{C}$ & & \\
\hline Simulations not generating runoff, $\%$ & $44.8 \mathrm{a}$ & $19.5 b$ & $31.6 a, b$ & $16.7 b$ & $21.2 b$ & 5.08 & $<0.05$ \\
\hline Infiltration rate, $\mathrm{mm} \cdot \mathrm{h}^{-1}$ & 65.91 & 62.54 & 62.32 & 56.56 & 55.43 & 2.31 & $=0.06$ \\
\hline Runoff, \% rainfall & $6.4 b$ & 16.4a,c & $12.7 \mathrm{~b}, \mathrm{c}$ & $20.7 a$ & $21.9 a$ & 2.7 & $<0.05$ \\
\hline Sediment concentration, $g \cdot L^{-1}$ & 0.04 & 0.03 & 0.05 & 0.09 & 0.08 & 0.03 & NS \\
\hline Total $\mathrm{P}$ concentration, $\mathrm{mg} \mathrm{PO}_{4}-\mathrm{P} \cdot \mathrm{L}^{-1}$ & 0.23 & 0.24 & 0.29 & 0.44 & 0.41 & 0.06 & $=0.08$ \\
\hline Sediment load, $\mathrm{kg} \cdot \mathrm{ha}^{-1} \cdot \mathrm{h}^{-1}$ & 1.4 & 4.3 & 5.9 & 8.4 & 16.5 & 5.0 & NS \\
\hline Total P load, $\mathrm{kg} \mathrm{PO} \mathrm{P}_{4}-\mathrm{P} \cdot \mathrm{ha}^{-1} \cdot \mathrm{h}^{-1}$ & $0.007 \mathrm{c}$ & $0.025 b, c$ & $0.025 b, c$ & $0.053 a, b$ & $0.07 a$ & 0.011 & $<0.05$ \\
\hline
\end{tabular}

${ }^{1}$ Forage treatments: $\mathrm{U}$ indicates ungrazed; HS, hay harvest/fall stockpile grazing; $10 \mathrm{R}, 10 \mathrm{~cm}$ rotational stocking; $5 \mathrm{R}, 5$-cm rotational stocking; $5 \mathrm{C}$, 5-cm continuous stocking.

${ }^{2}$ SEM indicates standard error of the mean; $n, 72$ (3 blocks $\times 3 \mathrm{y} \times 2$ slopes $\times 4$ seasons).

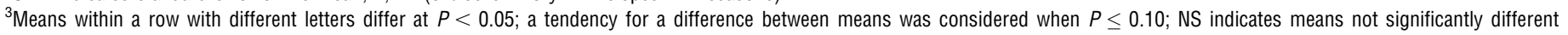
$(P>0.10)$.

improve rainfall infiltration (Naeth et al. 1990). No surface runoff was generated during $44.8 \% \pm 5.1 \%$ of rainfall simulations conducted in the U treatment, which did not differ from the $10 \mathrm{R}(31.6 \% \pm 5.1 \%)$ treatment, and was greater $(P<0.05)$ than the number of simulation events, which did not generate runoff in the HS $(19.5 \% \pm 5.1 \%), 5 \mathrm{R}(16.7 \% \pm 5.1 \%)$, and $5 \mathrm{C}(21.2 \% \pm 5.1 \%)$ treatments (Table 1$)$. In the current study, infiltration rate tended to be greater $(P=0.06)$ in the $\mathrm{U}$ $\left(65.9 \pm 2.3 \mathrm{~mm} \cdot \mathrm{h}^{-1}\right)$ paddock than in the harvested paddocks $\left(59.2 \pm 2.3 \mathrm{~mm} \cdot \mathrm{h}^{-1}\right)$. Percent precipitation lost as surface runoff from paddocks with the $U(6.4 \% \pm 2.7 \%)$ and 10R $(12.7 \% \pm 2.7 \%)$ treatments did not differ, but were less $(P<0.05)$ than that from paddocks with the $5 \mathrm{C}$ $(21.9 \% \pm 2.7 \%)$ and $5 \mathrm{R}(20.7 \% \pm 2.7 \%)$ treatments. Based on the percentage surface runoff and rainfall rate, surface runoff rate was $4.5,11.6,9.0,14.7$, and $15.5 \mathrm{~mm} \cdot \mathrm{h}^{-1}$ for the $\mathrm{U}$, HS, 10R, 5R, and 5C treatments, respectively, assuming a constant rate of runoff during the simulation. Sediment concentration in surface runoff did not differ among forage management treatments. The concentrations of total $P$ in runoff from paddocks with the $5 \mathrm{R}$ and $5 \mathrm{C}$ treatments tended to be greater $(P=0.08)$ than paddocks with $\mathrm{U}, \mathrm{HS}$, and $10 \mathrm{R}$ treatments.

Although some sediment and nutrient loss is expected to occur from ungrazed pastures with complete ground cover (McDowell et al. 2003; Elliot and Carlson 2004), livestock grazing increases the likelihood of higher concentrations of nutrients in surface runoff because of soil disturbance, plant damage, and the deposition of dung on the soil surface (Gillingham and Thorrold 2000). In the current study, sediment load in surface runoff from the $U$ treatment was $1.4 \pm 5.0$ $\mathrm{kg} \cdot \mathrm{ha}^{-1} \cdot \mathrm{h}^{-1}$. However, because of the large amount of variation both within and between treatments, sediment load did not differ among forage management treatments, though there was the general trend for sediment load to increase as grazing pressure increased (Table 1 ). In contrast, the total $\mathrm{P}$ load did not differ among paddocks with the U, HS, and 10R treatments, but was greater $(P<0.05)$ in paddocks with the $5 \mathrm{C}$ treatment. No significant forage management treatment by year interactions were observed for infiltration rate, percentage of surface runoff, concentrations of sediment, or total P in surface runoff, or for the total amount of sediment or P load in surface runoff. The proportion of rainfall lost as surface runoff and the total P load from the 10R treatment were not different from the $U$ treatment, suggesting that leaving approximately $10 \mathrm{~cm}$ of residual forage was sufficient to maintain the hydraulic conductivity of the pasture.

Bray-1 soil $\mathrm{P}\left(20.7 \pm 4.5 \mathrm{mg} \cdot \mathrm{kg}^{-1}\right)$ did not differ among forage management treatments. Soil moisture and surface roughness were greater $(P<0.05$; Table 2$)$ in ungrazed paddocks than in paddocks that were harvested by grazing or hay production. No differences, in these variables, were observed among the harvested forage treatments. Penetration resistance was lower $(P<0.05)$ in the upper $14.0 \mathrm{~cm}$ of soil in ungrazed paddocks than in paddocks with the other forage management treatments. This difference was greatest in the top $3.5 \mathrm{~cm}$ of the soil profile, with $\mathrm{U}(1199 \mathrm{kPa})$ being less resistant than HS (1 $528 \mathrm{kPa})$, which was less resistant than the $10 \mathrm{R}$ (1 $811 \mathrm{kPa})$, 5R (1 $963 \mathrm{kPa})$ and 5C (1 $872 \mathrm{kPa})$ that did not differ. At depths greater than $17.5 \mathrm{~cm}$, no difference was observed in penetration resistance among forage management treatments.

Soil moisture in the 5C $(16.9 \%)$ treatment tended to be lower $(P=0.08$; year $\times$ treatment $)$ in year 3 than in the other management treatments $(18.2 \%$ mean of $5 \mathrm{R}, 10 \mathrm{R}, \mathrm{HS})$ in that year. This effect may be an indication that change in the waterholding capacity of the soil had begun to occur in the $5 \mathrm{C}$ treatment, as a reduction in soil organic matter has been shown to result in a reduction in water-holding capacity of the soil (Naeth et al. 1991b; Betteridge et al. 1999). Had the study continued, this effect may have become significant as changes in soil characteristics that have an impact on hydrological properties may take longer to appear than the 3 years of the current study (Mapfumo et al. 2000).

Vegetative surface cover and greater forage sward height are known to reduce the amounts of nutrients entering streams from grazing lands (Nelson et al. 1996). Forage sward height and forage mass were greater $(P<0.05)$ in ungrazed paddocks than in harvested treatments (Table 2). Forage sward heights did not differ between paddocks with the HS and 10R treatments and were greater $(P<0.05)$ than either of the treatments grazed to $5 \mathrm{~cm}$. However, mean forage masses of paddocks with the $10 \mathrm{R}$ treatment were greater $(P<0.05)$ than paddocks with the HS treatment. Although the 5R and 5C treatments were grazed to heights of $5 \mathrm{~cm}$, the mean sward heights and forage masses at the time of the rainfall simulations of 
Table 2. Least squares means of the forage management effects on soil and forage characteristics measured simultaneous to rainfall simulations in 4 months over 3 years.

\begin{tabular}{|c|c|c|c|c|c|c|c|}
\hline & \multicolumn{5}{|c|}{ Treatment $^{1}$} & \multirow[b]{2}{*}{$\mathrm{SEM}^{2}$} & \multirow[b]{2}{*}{$P$ value $^{3}$} \\
\hline & $U$ & HS & $10 \mathrm{R}$ & $5 R$ & $5 C$ & & \\
\hline \multicolumn{8}{|l|}{ Soil characteristics } \\
\hline Soil moisture, \% & $22.9 a$ & $20.0 b$ & $20.7 b$ & $20.9 b$ & $19.8 b$ & 0.5 & $<0.05$ \\
\hline \multicolumn{8}{|l|}{ Penetration resistance, $\mathrm{kPa}$} \\
\hline $3.5 \mathrm{~cm}$ & $1199 a$ & $1528 b$ & $1811 \mathrm{c}$ & $1963 c$ & $1872 \mathrm{c}$ & 79 & $<0.05$ \\
\hline $7.0 \mathrm{~cm}$ & $1803 a$ & 2 292b & $2521 c$ & $2521 \mathrm{c}$ & $2682 \mathrm{c}$ & 63 & $<0.05$ \\
\hline $10.5 \mathrm{~cm}$ & 2 101a & $2590 b$ & 2 697b & $2598 b$ & $2781 b$ & 72 & $<0.05$ \\
\hline $14.0 \mathrm{~cm}$ & $2231 a$ & $2613 b$ & $2628 b$ & $2521 b$ & $2735 b$ & 78 & $<0.05$ \\
\hline $17.5 \mathrm{~cm}$ & 2323 & 2666 & 2613 & 2498 & 2705 & 91 & $=0.10$ \\
\hline Surface roughness, ${ }^{4} \mathrm{~cm}$ & $0.750 \mathrm{a}$ & $0.630 \mathrm{~b}$ & $0.677 \mathrm{~b}$ & $0.638 b$ & $0.635 b$ & 0.024 & $<0.05$ \\
\hline \multicolumn{8}{|l|}{ Forage characteristics } \\
\hline Sward height, $\mathrm{cm}$ & $19.3 a$ & $8.7 b, c$ & $10.8 b$ & $7.3 \mathrm{c}$ & $5.6 \mathrm{~d}$ & 0.6 & $<0.05$ \\
\hline Forage mass, $\mathrm{kg} \cdot \mathrm{ha}^{-1}$ & $4315 a$ & $1512 b$ & $2132 c$ & $1502 b$ & $1114 d$ & 117 & $<0.05$ \\
\hline Vegetative ground cover, \% & $99.2 \mathrm{a}$ & $95.7 a, b$ & $94.7 a, b$ & $91.9 b, c$ & $87.7 \mathrm{c}$ & 2.0 & $<0.05$ \\
\hline
\end{tabular}

${ }^{1}$ Forage management treatment: $U$ indicates ungrazed; HS, hay harvest/fall stockpile grazing; $10 \mathrm{R}, 10 \mathrm{~cm}$ rotational stocking; $5 \mathrm{R}, 5$-cm rotational stocking; $5 \mathrm{C}, 5-\mathrm{cm}$ continuous stocking. ${ }^{2}$ SEM indicates standard error of the mean; $n, 72$ ( 3 blocks $\times 3 y \times 2$ slopes $\times 4$ seasons).

${ }^{3}$ Means within a row with different letters differ at $P<0.05$; a tendency for a difference between means was considered when $P \leq 0.10$.

${ }^{4}$ Surface roughness was determined as the standard deviation in pin length of 41 pins over a $2-m$ length.

paddocks with the $5 \mathrm{R}$ treatment were greater $(P<0.05)$ than paddocks with the $5 \mathrm{C}$ treatment. Forage management treatment by year interactions were observed for forage sward height $(P<0.05)$ and forage mass $(P<0.05)$. Forage sward height in year 1 was greater in the $5 \mathrm{C}$ and $\mathrm{HS}$ treatments than in years 2 and 3. Paddocks with the $5 \mathrm{R}$ treatment had greater sward heights in year 2 than in years 1 and 3 , and paddocks with the $10 \mathrm{R}$ and $\mathrm{U}$ treatments had greater sward heights in year 3 than years 1 and 2 . These interactions were likely a result of the temporal variation of rainfall simulations relative to grazing periods. Whether a rainfall simulation was conducted near the beginning or end of the 35-day rest period in one of the rotational stocking systems would impact forage sward height and forage mass measurements. Forage mass followed the same general trends as did forage sward height.

The mean percentage of vegetative ground cover among paddocks with the U, 10R, and HS treatments $(96.5 \%)$ was greater $(P<0.05)$ than the $5 \mathrm{C}$ treatment $(87.7 \%)$. The primary role of forage cover in preventing erosion and nutrient loss is to decrease the kinetic energy of the raindrops before they strike the soil surface (Thurow et al. 1986). A significant forage management treatment by year interaction was observed for vegetative surface cover. Vegetative surface cover of paddocks in the $5 \mathrm{C}$ treatment increased from $83.6 \%$ in year 1 to $89.1 \%$ and $91.5 \%$ cover in years 2 and 3 , respectively, while surface cover in the other forage management treatments did not differ between years.

\section{Slope Effects}

Surface runoff, as a percentage of applied rainfall, was greater $(P<0.05$; Table 3$)$ from high-slope $(19.2 \%)$ than low-slope sites $(12.0 \%)$. This finding is similar to results reported by Mwendera and Saleem (1997) who found, across a wide range of grazing intensities, surface runoff increased when slope increased from $0 \%-4 \%$ to $4 \%-8 \%$. The greater surface runoff from high-slope areas resulted in greater $(P<0.05)$ sediment load coming from high-slope than from low-slope areas even though sediment concentration of surface runoff was not affected by surface slope. Shainberg et al. (1992) reported that this increase in sediment transport is partially related to an increase in flow velocity of surface runoff at higher slopes.

Total $\mathrm{P}$ concentrations tended to be greater $(P=0.08)$ from low-slope than high-slope sites. These results may partially be

Table 3. Least squares means of the effects of surface slope on surface runoff, soil, and forage characteristics from simulated rainfall.

\begin{tabular}{|c|c|c|c|c|}
\hline & \multicolumn{2}{|c|}{ Slope $^{1}$} & \multirow[b]{2}{*}{$\mathrm{SEM}^{2}$} & \multirow[b]{2}{*}{$P$ value $^{3}$} \\
\hline & High & Low & & \\
\hline \multicolumn{5}{|l|}{ Surface runoff characteristics } \\
\hline Infiltration rate, $\mathrm{mm} \cdot \mathrm{h}^{-1}$ & 57.95 & 63.16 & 1.26 & $<0.05$ \\
\hline Runoff, \% rainfall & 19.2 & 12.0 & 1.3 & $<0.05$ \\
\hline Sediment concentration, $g \cdot \mathrm{L}^{-1}$ & 0.06 & 0.06 & 0.02 & NS \\
\hline Total $\mathrm{P}$ concentration, $\mathrm{mg} \mathrm{PO}_{4}-\mathrm{P} \cdot \mathrm{L}^{-1}$ & 0.28 & 0.36 & 0.03 & $=0.08$ \\
\hline Sediment load, $\mathrm{kg} \cdot \mathrm{ha}^{-1} \cdot \mathrm{h}^{-1}$ & 10.3 & 4.3 & 2.4 & $<0.05$ \\
\hline Total P load, $\mathrm{kg} \mathrm{PO}_{4}-\mathrm{P} \cdot \mathrm{ha}^{-1} \cdot \mathrm{h}^{-1}$ & 0.039 & 0.033 & 0.005 & NS \\
\hline \multicolumn{5}{|l|}{ Soil characteristics } \\
\hline Bray-1 P, $\mathrm{mg} \cdot \mathrm{kg}^{-1}$ & 17.1 & 24.4 & 2.7 & $=0.06$ \\
\hline Soil moisture, \% & 20.5 & 21.3 & 0.3 & $=0.09$ \\
\hline \multicolumn{5}{|l|}{ Forage characteristics } \\
\hline Sward height, $\mathrm{cm}$ & 9.9 & 10.8 & 0.3 & $<0.05$ \\
\hline Forage mass, $\mathrm{kg} \cdot \mathrm{ha}^{-1}$ & 2008 & 2222 & 67 & $<0.05$ \\
\hline Vegetative ground cover, \% & 93.1 & 94.6 & 1.0 & $=0.09$ \\
\hline
\end{tabular}

${ }^{1}$ Slope classification: High indicates $7^{\circ}-15^{\circ}$; Low, $0^{\circ}-7^{\circ}$.

${ }^{2}$ SEM indicates standard error of the mean; $n, 180$ ( 3 blocks $\times 5$ treatments $\times 3$ y $\times 4$ seasons).

${ }^{3}$ Means within a row with different letters differ at $P<0.05$; a tendency for a difference between means was considered when $P \leq 0.10$; NS indicates means not significantly different $(P>0.10)$. 


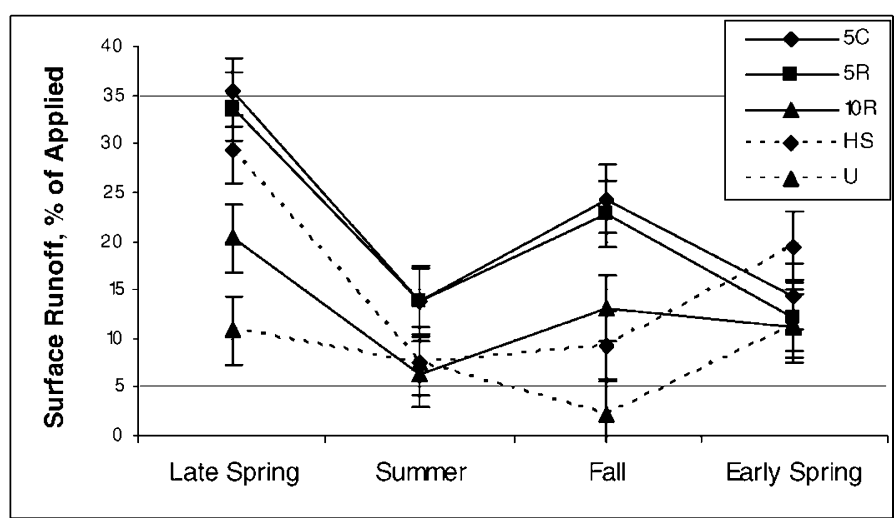

b

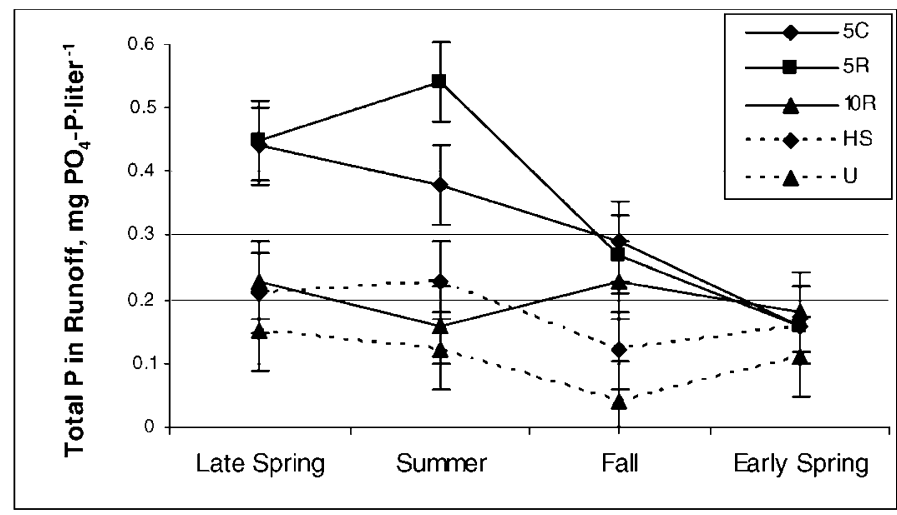

$\mathrm{C}$

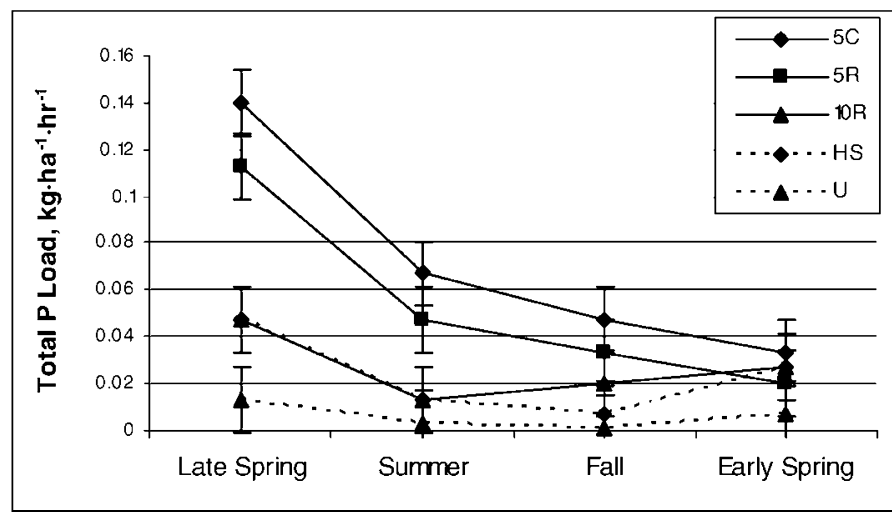

Figure 1. Treatment by season interactions $(P<0.05)$ on surface runoff $(S E M=3.5)$; $\mathbf{a}$, total $P$ concentration $(S E M=0.062) ; \mathbf{b}$, total $P$ load (SEM $=0.014)$; c, from pastures during simulated rainfall, $n=18$ (3 blocks $\times 3$ years $\times 2$ slopes).

caused by the tendency for greater $(P=0.06)$ Bray- $1 \mathrm{P}$ in lowslope than at high-slope sites of the paddocks. The greater volume of runoff and the lower concentrations of total $\mathrm{P}$ in runoff from high-slope than low-slope sites resulted in no difference in total P loads coming from the high- and low-slope sites. No forage management treatment by slope interactions were observed for infiltration rate, surface runoff, concentrations of sediment or $\mathrm{P}$ in surface runoff, or the total amount of sediment or $\mathrm{P}$ load in surface runoff.

Soil moisture $(P=0.09)$ tended to be greater at low-slope than at high-slope sites of the paddocks. In spite of the difference in soil moisture, penetration resistance to a depth of $35 \mathrm{~cm}$ and surface roughness did not differ between highand low-slope sites. No slope by forage management treatment interactions occurred for Bray-1 soil $\mathrm{P}$, soil moisture, penetration resistance in the upper $3.5 \mathrm{~cm}$ of the soil, or surface roughness.

Forage sward height and forage mass were less $(P<0.05)$ at high-slope than low-slope sites (Table 3 ). The percentage of vegetative ground cover also tended to be less $(P=0.09)$ at high- than low-slope sites. The lower sward height, forage mass, and vegetative ground cover at high slope may partially be related to lower moisture concentrations on high-sloping areas as reported by Guretzky et al. (2004) and observed in the current study. No slope by forage management treatment interactions were observed for forage sward height, forage mass, or vegetative surface cover.

\section{Seasonal Effects}

Infiltration rate in pastures is often greater during dry than wet seasons (Elliott and Carlson 2004), while surface runoff is greater during wet than dry seasons (Naeth et al. 1990; Merz and Plate 1997), largely as a result of differences in antecedent soil moisture. In the current study, greater $(P<0.05)$ infiltration occurred during the summer $\left(68.11 \pm 1.62 \mathrm{~mm} \cdot \mathrm{h}^{-1}\right)$ than during the late spring $\left(54.64 \pm 1.62 \mathrm{~mm} \cdot \mathrm{h}^{-1}\right)$. The percentage of surface runoff was greatest $(P<0.05)$ during the late spring $(25.9 \% \pm 1.6 \%)$, intermediate during the fall $(14.5 \% \pm 1.6 \%)$ and early spring $(13.7 \% \pm 1.6 \%)$, and lowest during the summer $(5.9 \% \pm 1.6 \%)$ sampling periods. Mean concentrations of sediment in the runoff did not differ among seasons.

Mean concentrations of total $\mathrm{P}$ in runoff during the early spring $\left(0.24 \pm 0.04 \mathrm{mg} \mathrm{PO}_{4}-\mathrm{P} \cdot \mathrm{L}^{-1}\right)$ were lower $(P<0.05)$ than during the late spring $\left(0.34 \pm 0.04 \mathrm{mg} \mathrm{PO}_{4}-\mathrm{P} \cdot \mathrm{L}^{-1}\right)$ and summer $\left(0.45 \pm 0.04 \mathrm{mg} \mathrm{PO}_{4}-\mathrm{P} \cdot \mathrm{L}^{-1}\right)$, but did not differ from measurements in the fall $\left(0.26 \pm 0.04 \mathrm{mg} \mathrm{PO}_{4}-\mathrm{P} \cdot \mathrm{L}^{-1}\right)$. Sediment load in runoff from rainfall simulations in the late spring $\left(13.7 \pm 2.8 \mathrm{~kg} \cdot \mathrm{ha}^{-1} \cdot \mathrm{h}^{-1}\right)$ was greater $(P<0.05)$ than during the other seasons, which did not differ, and averaged $5.17 \pm 2.8 \mathrm{~kg} \cdot \mathrm{ha}^{-1} \cdot \mathrm{h}^{-1}$. Total P load in runoff from rainfall simulations in the late spring $\left(0.072 \pm 0.006 \mathrm{~kg} \cdot \mathrm{ha}^{-1} \cdot \mathrm{h}^{-1}\right)$ was greater $(P<0.05)$ than during the other seasons, which did not differ, and averaged $0.024 \pm 0.006 \mathrm{~kg} \cdot \mathrm{ha}^{-1} \cdot \mathrm{h}^{-1}$. Elliott et al. (2002) reported similar seasonal variability in sediment load in surface runoff from pasture, with peak erosion occurring during the wetter portion of the year.

There were no forage management treatment by season interactions for infiltration rate, sediment concentration in surface runoff, or total sediment load in surface runoff. Significant $(P<0.05)$ forage management treatment by season interactions existed for percentage runoff, concentrations of total $\mathrm{P}$ in runoff (Fig. 1), and total $\mathrm{P}$ load by surface runoff $(P<0.05)$.

The concentration of Bray-1 P in surface $(0-5 \mathrm{~cm})$ soil was lower $(P<0.05)$ in the early spring $\left(18.5 \pm 2.2 \mathrm{mg} \cdot \mathrm{kg}^{-1}\right)$ than during the other seasons, which averaged $21.4 \pm 2.2$ $\mathrm{mg} \cdot \mathrm{kg}^{-1}$. The low concentrations of total $\mathrm{P}$ in runoff in the early spring may be partially related to the lower soil Bray-1 P during this season. The moisture content of soil in the upper 
$5 \mathrm{~cm}$ was lower $(P<0.05)$ during the summer $(12.9 \pm 0.4 \%)$ than during the fall $(21.7 \pm 0.4 \%)$, which was lower than either the late or early spring, which averaged $24.6 \pm 0.4$ and $24.4 \pm 0.4 \%$, respectively. Relatively small changes in soil moisture are able to significantly alter penetration resistance of the soil (Pires da Silva et al. 2003). Therefore, the differences in soil moisture likely resulted in soil penetration resistances at all depths being greater $(P<0.05)$ during the summer season than other seasons. The differences in soil penetration were most extreme in the upper $3.5 \mathrm{~cm}$ of the soil profile, being $2477 \pm 59 \mathrm{kPa}$ during the summer, $1730 \pm 59$ $\mathrm{kPa}$ during the fall, and $1265 \pm 59$ and $1204 \pm 59 \mathrm{kPa}$ during the early and late spring, respectively. No forage management treatment by season interactions existed for Bray-1 P, soil moisture, or penetration resistance at a depth of $10.5,14$, or $35 \mathrm{~cm}$. Penetration resistance in the HS treatment was similar to that of the $U$ treatment during the late spring, while it was similar to that of the grazed paddocks at the other times of the year (treatment $\times$ season, $P<0.05$ ) at the 3.5-, 7.0-, 17.5-, 21-, 24.5-, 28.0-, and 35.0-cm depths.

Mean forage sward height was greater $(P<0.05)$ during the late spring $(15.3 \pm 0.3 \mathrm{~cm})$ than during the other seasons and decreased through the summer $(11.1 \pm 0.3 \mathrm{~cm})$, fall $(8.5 \pm 0.3$ $\mathrm{cm})$, and following early spring $(6.5 \pm 0.3 \mathrm{~cm})$ when averaged across treatments. In spite of the difference in sward height, mean forage mass did not differ among seasons, when averaged across treatments. Mean vegetative ground cover was lower $(P<0.05)$ during the summer $(91.4 \% \pm 1.1 \%)$ than during the late spring $(94.7 \% \pm 1.1 \%)$, fall $(96.2 \% \pm 1.1 \%)$, or early spring $(92.8 \% \pm 1.1 \%)$. Vegetative surface cover of the $U$ treatment remained constant throughout the year (99\%), while the harvested treatments remained constant from late spring into summer, increased in the fall, and remained constant into the early spring (treatment $\times$ season, $P<0.05$ ).

\section{Regressions Predicting Infiltration Rate, Surface Runoff and Sediment and Total P Load}

Of the characteristics measured, a model including soil moisture, forage mass, surface cover, and penetration resistance at 3.5 and $30.5 \mathrm{~cm}$ was the best predictor of infiltration rate $\left(R^{2}=0.11\right)$. Of the variables measured, forage mass $\left(R^{2}=0.10\right)$ and sine of surface slope in radians $\left(R^{2}=0.07\right)$ were most highly related to surface runoff. The vegetative surface cover was the best predictor of sediment load in surface runoff $\left(y=98.962-1.097 x ; R^{2}=0.17\right)$, where $y$ is the sediment load in $\mathrm{kg} \cdot \mathrm{ha}^{-1} \cdot \mathrm{h}^{-1}$ and $x$ is the percentage of vegetative surface cover, and total $\mathrm{P}$ load in surface runoff $\left(y=0.222-0.0021 x ; R^{2}=0.13\right)$ where $y$ is the phosphorus load in $\mathrm{kg} \cdot \mathrm{ha}^{-1} \cdot \mathrm{h}^{-1}$ and $x$ is the percentage of vegetative surface cover. The model with the greatest $R^{2}(0.23)$ generated for any of the dependent variables was for surface runoff, but this model included 8 independent variables. The number of variables included and the relatively low $R^{2}$ values reflect the complex nature of the forage systems as they relate to hydrological processes and sediment and $\mathrm{P}$ load. These results are similar to work by Pearce et al. (1998), who concluded that a variety of soil and forage characteristics are important in the control of hydrological processes. Even though many factors are important, soil moisture appears to be important in
Total P in Runoff in Relation to Soil Bray-1 P

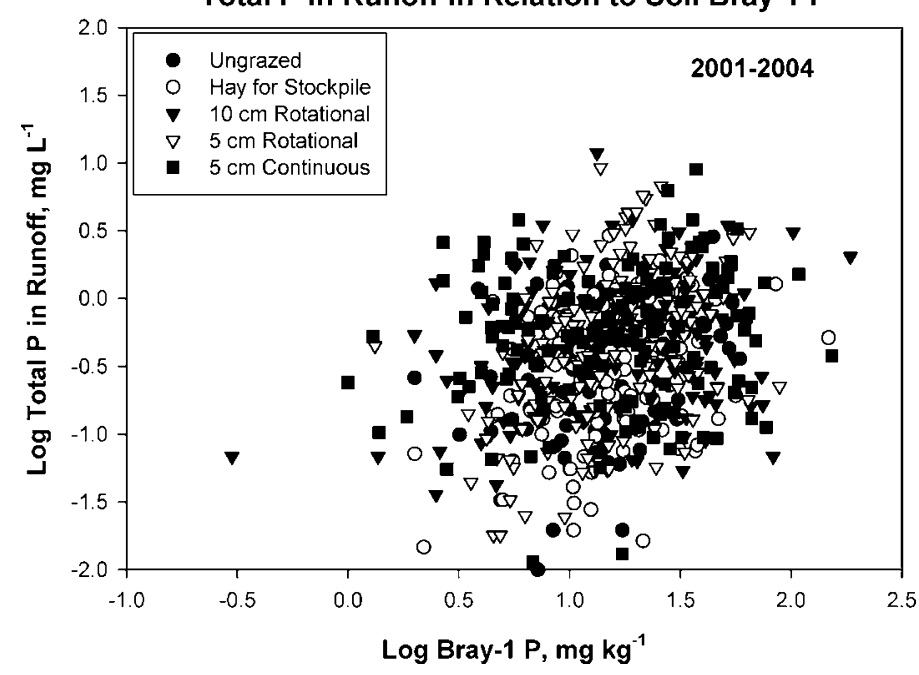

Figure 2. Total $P$ in runoff in relation to soil Bray-1 $P$.

controlling infiltration and surface runoff, whereas the amount of vegetative surface cover, penetration resistance in the upper $3.5 \mathrm{~cm}$ of the soil, and the slope of the land were important in the control of surface runoff and sediment and P load in surface runoff.

In the current study, the percentage vegetative cover on the soil surface was significantly correlated with infiltration rate, surface runoff, and sediment and total P loads in runoff. Decreasing surface cover exposes the soil surface to greater raindrop impact and increases sediment movement through splash erosion (Pearce et al. 1998). The lowest amount of vegetative surface cover occurred in the $5 \mathrm{C}$ treatment in the current study. Switching from continuous stocking (5C) to rotational stocking $(5 \mathrm{R})$ with the same target forage sward height of $5 \mathrm{~cm}$ in smooth bromegrass pastures allowed for forage regrowth, prevented bare patches from developing within the pasture and helped to maintain vegetative cover at greater than $90 \%$. While the $5 \mathrm{R}$ paddocks had greater surface cover than did the 5C paddocks, this difference was not enough to result in a reduction of sediment or P loads in surface runoff. The $10 \mathrm{R}$ and HS treatments maintained surface cover at approximately $95 \%$ and did not differ from an ungrazed pasture in the amount of bare ground exposed or in the amount of sediment or total P loads in surface runoff.

Previous research has suggested that concentrations of total $\mathrm{P}$ in runoff are highly correlated with plant-available $\mathrm{P}$ in the surface soil (Sharpley 1995; Pote et al. 1996; Sauer et al. 2000). In the current study, the relationships were statistically significant, but weak, regardless of grazing treatment or grazing year (Fig. 2). The strongest relationships were between total $\mathrm{P}$ concentrations and Bray- $1 \mathrm{P}\left(R^{2}=0.12, P \leq 0.0002\right)$ for the $5-\mathrm{cm}$ rotational grazing treatment. Our study area consisted of 3 soil types that were not distributed evenly among the rainfall simulation sites, so that the relationship between $\mathrm{P}$ in runoff and soil P may have varied with soil type as reported by Sharpley (1995). More important, some of the measured Bray-1 $P$ values reflected sampling of both soil and manure recently deposited on the soil surface. To use Bray-1 $\mathrm{P}$ as a predictor of total $\mathrm{P}$ in runoff, separate relationships would need to be developed for sites with and without recent manure deposition. 


\section{MANAGEMENT IMPLICATIONS}

Some sediment and P loss will occur in surface runoff from pastures, even in the absence of forage harvest by either grazing or hay harvest. Losses can be accelerated by forage harvest by grazing or hay harvest. Forage management practices that leave adequate forage residue on the surface, such as the $10 \mathrm{R}$ and HS treatments in smooth bromegrass pastures, will improve infiltration rate and protect the soil surface from the force of raindrops impacting the soil surface. These factors will result in a reduction of sediment and nutrient transport from the soil surface, particularly from areas of high slope. Maintaining adequate surface cover is the most important factor in limiting sediment and P loads in surface runoff from pastures. However, the poor correlation between surface cover and sediment and total P loads, in the current study, indicates that other forage, soil, and site characteristics such as forage mass, sward height, soil moisture, soil organic matter, soil $\mathrm{P}$, and slope are also important in the control of rainfall infiltration and sediment and $\mathrm{P}$ losses. Areas of high slope have greater potential to generate surface runoff and sediment loss than do areas with low slope. Managing these areas separately, to maintain sufficient forage cover and reduce the amount of bare ground, may be necessary to reduce sediment loss from hilly pastures. Greater surface runoff, sediment loss, and total $\mathrm{P}$ losses occurred during the late spring than at other times of the year. It may be necessary to avoid grazing of pastures near surface waters during this period to minimize surface runoff, sediment load, and P load.

\section{ACKNOWLEDGMENTS}

The authors would like to thank the numerous graduate and undergraduate students who assisted with data collection and analysis and the staff at the Iowa State University Rhodes Research Farm for assistance with animal management.

\section{LITERATURE CITED}

Alderfer, R. B., and R. R. Robinson. 1947. Runoff from pastures in relation to grazing intensity and soil compaction. Journal of the American Society of Agronomy 39(11):948-958.

American Public Health Association (APHA). 1995. Standard Methods for the examination of water and wastewater. 19th ed. Washington, DC: American Public Health Association. 993 p.

AOAC. 2003. Official methods of analysis of AOAC international. 17th ed. Gaithersburg, MD: AOAC International. $2200 \mathrm{p}$.

Betteridge, K., A. D. Mackay, T. G. Shepherd, D. J. Barker, P. J. Budding, B. P. Devantier, and D. A. Costall. 1999. Effect of cattle and sheep treading on surface configuration of a sedimentary hill soil. Australian Journal of Soil Research 37:743-760.

BOWYER-BOWER, T. A. S., AND T. P. BURT. 1989. Rainfall simulators for investigating soil response to rainfall. Soil Technology 2:1-16.

Bray, R. H., AND L. T. KuRTz. 1945. Determination of total, organic, and available forms of phosphorus in soils. Soil Science 59:39-45.

Clary, W. P., and W. C. Leininger. 2000. Stubble height as a tool for management of riparian areas. Journal of Range Management 53:562-573.

Council for Agricultural Science and Technology (CAST). 2002. Environmental impacts of livestock on US grazing lands. Issue paper 22. Ames, IA: CAST.

Elliott, A. H., and W. T. Carlson. 2004. Effects of sheep grazing episodes on sediment and nutrient loss in overland flow. Australian Journal of Soil Research 42:213-220.
Elliott, A. H., Y. Q. Tain, J. C. Rutherford, and W. T. Carlson. 2002. Effect of cattle treading on interrill erosion from hill pasture: modeling concepts and analysis of rainfall simulator data. Australian Journal of Soil Research 40: 963-976.

Entz, M. H., V. S. Baron, P. M. Carr, D. W. Meyer, S. R. Smith, JR., and W. P. McCaughy. 2002. Potential of forages to diversify cropping systems in the northern Great Plains. Agronomy Journal 94:240-250.

Fribourg, H. A., and K. W. Bell. 1984. Yield and composition of tall fescue stockpiled for different periods. Agronomy Journal 76:929-934.

Gard, L. E., R. F. Fuelleman, C. A. Van Dorn, and W. G. Kammlade. 1943. Runoff from pasture land as affected by soil treatment and grazing management and its relationship to botanical and chemical composition and sheep production. Journal of the American Society of Agronomy 35(4):332-347.

Gburek, W. E., A. N. Sharpley, L. Heathwaite, and G. J. Folmar. 2000. Phosphorus management at the watershed scale: a modification of the phosphorus index. Journal of Environmental Quality 29:130-144.

Gilley, J. E., B. D. Patton, P. E. Nyren, and J. R. Simanton. 1996. Grazing and hay effects on runoff and erosion from a former conservation reserve program site. Applied Engineering in Agriculture 12(6):681-684.

Gillingham, A. G., AND B. S. Thorrold. 2000. A review of New Zealand research measuring phosphorus in runoff from pastures. Journal of Environmental Quality 29:88-96.

Gonzalez, L., And B. F. J. Manly. 1998. Analysis of variance by randomization with small data sets. Environmetrics 9:53-65.

Gunn, R., AND G. D. Kinzer. 1949. The terminal velocity of water drops and raindrops in stagnant air. Journal of Meteorology 6:243-248.

Guretzky, J. A., K. J. Moore, C. L. Burras, and E. C. Brummer. 2004. Distribution of legumes along gradients of slope and soil electrical conductivity in pastures. Agronomy Journal 96:547-555.

Hermann, M. L., J. R. Russell, and S. K. Barnhart. 2002. Evaluation of hay-type and grazing-tolerant alfalfa cultivars in season-long or complementary rotational stocking systems for beef cows. Journal of Animal Science 80(3): 768-779.

Huff, F. A., And J. R. Angel. 1992. Rainfall frequency atlas of the Midwest. Bulletin 71. Champaign, IL: Illinois State Water Survey. $141 \mathrm{p}$.

Iowa State University (ISU). 2002. A general guide for crop nutrient and limestone recommendations in lowa. PM 1688. Ames, IA: ISU.

LiU, B. Y., M. A. Nearing, and L. M. Risse. 1994. Slope gradient effects on soil loss for steep slopes. Transactions of the ASAE 37(6):1834-1840.

Manley, W. A., R. H. Hart, M. S. Samuel, M. A. Smith, J. W. Waggoner, JR., and J. T. MankEY. 1997. Vegetation, cattle, and economic responses to grazing strategies and pressures. Journal of Range Management 50:638-646.

Mapfumo, E., D. S. Chanasyk, V. S. Baron, and M. A. Naeth. 2000. Grazing impacts on selected soil parameters under short-term forage sequences. Journal of Range Management 53:466-470.

McDowell, R. W., J. J. Drewry, R. J. Paton, P. L. Carey, R. M. Monaghm, and L. W. Condron. 2003. Influence of soil treading on sediment and phosphorus losses in overland flow. Australian Journal of Soil Research 41:949-961.

Merz, B., and E. J. Plate. 1997. An analysis of the effects of spatial variability of soil and soil moisture on runoff. Water Resources Research 33(12): 2909-2922.

Mwendera, E. J., and M. A. Mohamed Saleem. 1997. Infiltration rates, surface runoff, and soil loss as influenced by grazing pressure in the Ethiopian highlands. Soil Use and Management 13(1):29-35.

Naeth, M. A., A. W. Balley, D. S. Chanasyk, and D. J. Pluth. 1991a. Water holding capacity of litter and soil organic matter in mixed prairie and fescue grassland ecosystems of Alberta. Journal of Range Management 44(1): 13-17.

Naeth, M. A., A. W. Bailey, D. J. Pluth, D. S. Chanasyk, and R. T. Hardin. 1991b. Grazing impacts on litter and soil organic matter in mixed prairie and fescue grassland ecosystems of Alberta. Journal of Range Management 44(1): 7-12.

Naeth, M. A., D. J. Pluth, D. S. Chanasyk, A. W. Bailey, and A. W. Fedkenheuer. 1990. Soil compacting impacts of grazing in mixed prairie and fescue grassland ecosystems of Alberta. Canadian Journal of Soil Science 70:157-167. 
National Oceanic and Atmospheric Administration (NOAA). 2001. Climatological data: annual summary; lowa. 112(13). Asheville, NC: United States National Oceanic and Atmospheric Administration. $36 \mathrm{p}$.

National Oceanic and Atmospheric Administration (NOAA). 2002. Climatological data: annual summary; Iowa. 113(13). Asheville, NC: United States National Oceanic and Atmospheric Administration. $36 \mathrm{p}$.

National Oceanic and Atmospheric Administration (NOAA). 2003. Climatological data: annual summary; lowa. 114(13). Asheville, NC: United States National Oceanic and Atmospheric Administration. $36 \mathrm{p}$.

National Oceanic and Atmospheric Administration (NOAA). 2004. Climatological data: annual summary; lowa. 115(13). Asheville, NC: United States National Oceanic and Atmospheric Administration. $36 \mathrm{p}$.

Nelson, P. N., E. Cotsaris, and J. M. Oades. 1996. Nitrogen, phosphorus, and organic carbon in streams draining two grazing catchments. Journal of Environmental Quality 25:1221-1229.

Pearce, R. A., M. J. Trlica, W. C. Leininger, D. E. Mergen, and G. Frasier. 1998. Sediment movement through riparian vegetation under simulated rainfall and overland flow. Journal of Range Management 51:301-308.

Pinchak, W. E., M. A. Smith, R. H. HaRt, and J. W. Waggoner, JR. 1991. Beef cattle distribution patterns on foothill range. Journal of Range Management 44(3):267-275.

Pires da Silva, A., S. Imhoff, And M. Corsi. 2003. Evaluation of soil compaction in an irrigated short-duration grazing system. Soil and Tillage Research 70:83-90.
Pote, D. H., T. C. Daniel, A. N. Sharpley, P. A. Moore, JR., D. R. Edwards, and D. J. Nichols. 1996. Relating extractable soil phosphorus to phosphorus losses in runoff. Soil Science Society of America Journal 60:855859.

SAS. 1999. SAS/STAT user's guide: statistics. Version 8. Cary, NC: SAS Institute. Available at: http://www2.stat.unibo.it/ManualiSas/stat/pdfidx.htm. Accessed 30 June 2006.

Sauer, T. J., T. C. Daniel, D. J. Nichols, C. P. West, P. A. Moore, JR., and G. L. WheELER. 2000. Runoff water quality from poultry litter-treated pasture and forest sites. Journal of Environmental Quality 29:515-521.

ShainberG, I., D. Warrington, and J. M. LafLen. 1992. Soil dispersibility, rain properties, and slope interaction in rill formation and erosion. Soil Science Society of America Journal 56:278-283.

Sharpley, A. N. 1995. Dependence of runoff phosphorus on extractable soil phosphorus. Journal of Environmental Quality 24:920-926.

SMECK, N. E. 1985. Phosphorus dynamics in soils and landscapes. Geoderma 36:185-199.

Thurow, T. L., W. H. Blackburn, and C. A. Taylor, JR. 1986. Hydrologic characteristics of vegetative types as affected by livestock grazing systems, Edwards Plateau, Texas. Journal of Range Management 39(6): 505-509.

Venables, B. D., And B. D. Ripley. 1994. Modern applied statistics with S-plus. New York, NY: Springer. 